\title{
Barium sulphate aspiration pneumonia in a cat with megaesophagus and dextroposition of the aortic arch: case report
}

\author{
[Pneumonia aspirativa por sulfato de barrio em gato com megaesôfago e destroposição \\ de arco da aorta: relato de caso] \\ J.A. Barrera-Zarate, B.A. Paiva, D.P. Ferreira, F.S. Alves, J.P.H. Sato, R.M.C. Guedes* \\ Escola de Veterinária - Universidade Federal de Minas Gerais - Belo Horizonte, MG
}

\begin{abstract}
A six-month-old female cat suffered aspiration of an abundant amount of barium sulfate during a radiographic procedure for the diagnosis of megaesophagus. Latero-lateral contrast radiography revealed severe dilation of the thoracic esophagus cranial to the base of the heart. Persistence of the right aortic arch was suspected and later confirmed during corrective surgery. Accumulation of barium sulfate, used as a contrast agent, was clearly observed in the lumen of the bronchi, bronchioles, and alveoli in the radiographic image. Days after the surgery, the animal developed severe respiratory distress, which resulted in death. Cytology results and histology analysis using polarized light demonstrated that the lumen of bronchi, bronchioles, and alveoli exhibited evident histiocytic infiltration with cytoplasm filled by abundant amorphous refractive granular material consistent with barium sulfate. In this report, we describe the anatomical, cytological, histopathological (using polarized light), and x-ray findings of a case of barium sulfate aspiration pneumonia in a cat resulting from the use of this contrast medium for the diagnosis of megaesophagus secondary to persistent right aortic arch.
\end{abstract}

Keywords: pathology-respiratory tract, congenital heart defects, barium sulfate, pathology-gastrointestinal tract, radiology-thoracic

\section{RESUMO}

Uma gata de seis meses aspirou grande quantidade de sulfato de bário durante procedimento radiográfico para diagnóstico de megaesôfago. Contraste radiográfico látero-lateral revelou dilatação de esôfago torácico até a base do coração. Persistência do arco aórtico direito foi confirmada durante cirurgia corretiva. Acúmulo de sulfato de bário, utilizado como agente de contraste, foi observado no lúmen de brônquios, bronquíolos e alvéolos à imagem radiográfica. Dias após a cirurgia o animal desenvolveu insuficiência respiratória grave e evoluiu para óbito. Resultado de citologia e histologia utilizado luz polarizada demonstrou que lúmen de brônquios, bronquíolos e alvéolos mostraram infiltração histológica com citoplasma cheio de material refratário granular amorfo compatível com sulfato de bário. Nesse relatório, descrevemos achados anatômicos, citológicos, histopatológicos e radiográficos de um caso de pneumonia aspirativa em gata resultante do uso desse meio de contraste para diagnóstico de megaesôfago secundário a persistência do arco aórtico direito.

Palavras-chave: vias respiratórias, defeitos cardíacos congênitos, sulfato de bário, trato gastrointestinal, anatomia patológica, radiologia torácica

\section{INTRODUCTION}

Radiographic contrast studies of the upper gastrointestinal tract are routinely used in veterinary medicine for diagnoses in animals

Recebido em 21 de maio de 2017

Aceito em 3 de janeiro de 2018

*Autor para correspondência (corresponding author)

E-mail: guedesufmg@gmail.com with clinical signs of vomiting, dysphagia, diarrhea, and abdominal pain (Meola et al., 2008). Alternatively, these radiographic methods are used to identify anatomic abnormalities such as foreign bodies, esophageal dilatation due to accumulation of fluid or gas, megaesophagus, 
vascular abnormalities, and aspiration pneumonia (Levine et al., 2014). Barium sulfate is a relatively insoluble salt that is widely used as radiographic contrast medium in the diagnosis of these gastrointestinal problems (Forbes, 1989; Katsanoulas et al., 2007).

Accidental aspiration of barium and the presence of this material in the lungs during radiological studies of the upper gastrointestinal tract are potential complications (Forbes, 1989; Katsanoulas et al., 2007). Due to the inert characteristics of barium sulfate, aspiration of this material usually does not cause of severe lung injury but may cause chemical pneumonia and respiratory infection when simultaneous aspiration of gastric contents occurs (Katsanoulas et al., 2007; Santos and Steen, 2014). However, cases of acute inflammation or death in humans with barium sulfate preparations of high or low density have been described (Katsanoulas et al., 2007; Santos and Steen, 2014).

The clinical course and prognosis vary depending on the amount of inhaled barium sulfate (Santos and Steen, 2014). Small amounts are well tolerated in the tracheobronchial portion, where the majority of the particles are eliminated by coughing or the mucociliary apparatus (Jackson et al., 2014). Unremoved particles accumulate in the alveolar space and are phagocytosed by alveolar macrophages, while others may pass directly through the alveolar epithelium (Katsanoulas et al., 2007; Jackson et $a l ., 2014)$. Alveolar and peribronchial interstitial tissue may develop mild interstitial fibrosis (Jackson et al., 2014). Barium sulfate particles can be found years later in the pulmonary parenchyma, alveolar macrophages, and tracheobronchial lymph nodes ${ }^{6}$ without interference with lung function or risk of developing a severe pulmonary infection (Meola et al., 2008; Jackson et al., 2014). This asymptomatic condition is called baritosis in human medicine (Jackson et al., 2014).

When barium sulfate is aspirated in large quantities, a mechanical obstruction is induced in the bronchial and alveolar spaces, leading to ventilation and perfusion failure due to interference with hematosis, which induces respiratory failure that may compromise the patient's life (Santos and Steen, 2014). Due to the high atomic weight of barium $(z=56)$, accumulation of this material in the lungs produces opaque spots, which are observed in radiography as white areas with different distribution patterns and are determined by lung clearance mechanisms such as coughing, mucociliary cleaning, and cell intake (Katsanoulas et al., 2007; Jackson et al., 2014).

Predisposing factors for aspiration of contrast medium could include low levels of consciousness and swallowing disorders due to deficiencies or alterations in esophageal motility (Forbes, 1989; Katsanoulas et al., 2007; Santos and Steen, 2014). These alterations in the esophagus can be caused, as in this case, by abnormalities in the development of vascular structures in the heart, resulting in involvement of the esophagus in these vascular defects (Kyles, 2012). These types of congenital vascular abnormalities are rarely reported in cats, but when present, the most commonly affected breeds are Persian and Siamese (Kyles, 2012; Tremolada et al., 2012). The most common abnormality in these breeds is the persistence of right aortic arch with the left arterial ligament extending between the left pulmonary artery and right persistent aortic arch (patent ductus arteriosus), resulting in narrowing of the esophagus by the vascular ring, leading to dilatation of the cervical esophagus and dysphagia. Affected animals may present with malnutrition and slower body growth, but normal or increased appetite (Kyles, 2012).

\section{CASE REPORT}

A six-month-old short hair female cat, weighting $3.01 \mathrm{~b}$ with a history of multiple episodes of vomiting (three to four times per day) after ingestion of food was treated at the Veterinary Hospital of the Universidade Federal de Minas Gerais (UFMG-VH). Five days before treatment at UFMG-VH, the animal had been evaluated at a private veterinary clinic, where it was diagnosed with megaesophagus and suspected of persistent right aortic arch based on contrast (barium sulfate) radiography findings. The radiographic images indicated a marked increase in the diameter of the cranial thoracic segment of the esophagus with retention of the contrast medium at the level of the heart base. The contrast medium had also accumulated in the lumen of the bronchi, bronchioles, and alveoli, 
suggesting aspiration of barium sulfate during the radiographic procedure (Figure 1). Upon clinical examination at the UFMG-VH, the animal exhibited poor body condition, a rectal temperature of $100.04^{\circ} \mathrm{F}$, a respiratory rate of $30 \mathrm{rpm}$, a heart rate of $160 \mathrm{bpm}$ (tachycardia), and swelling of the neck.

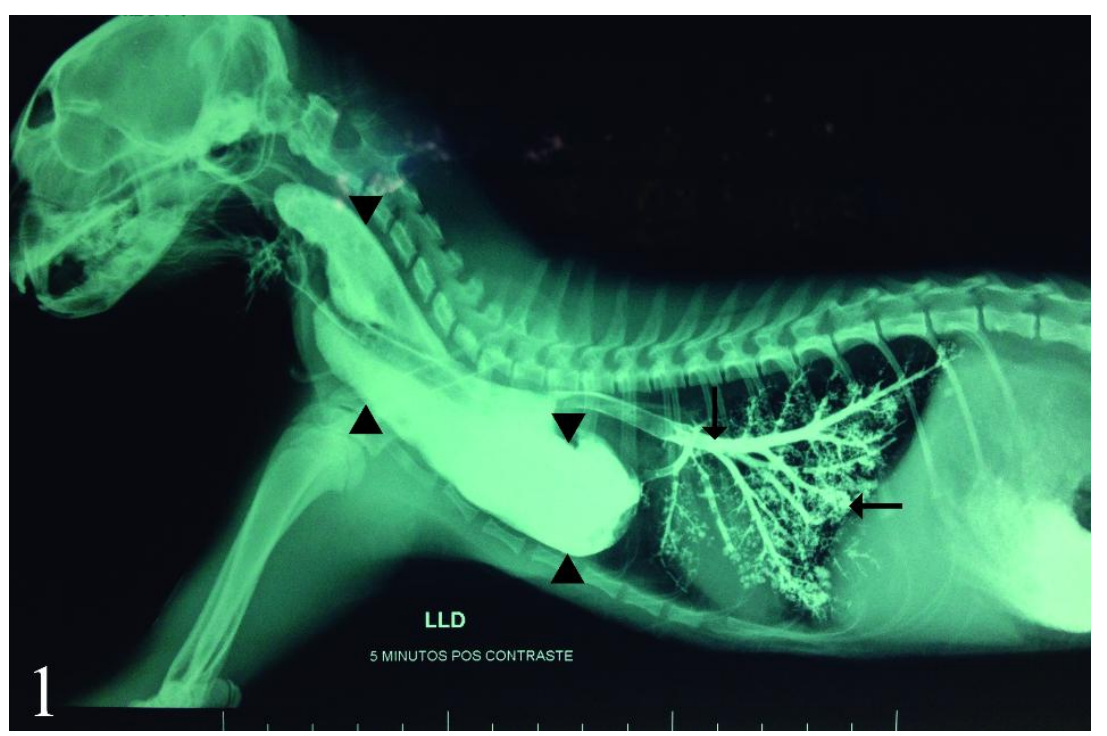

Figure 1. Six-month-old female cat. Thoracic latero-lateral radiography. Increased esophageal diameter with retention of contrast medium at the cardiac base is shown (arrowheads). The presence of the contrast medium in the alveoli and bronchial tree is shown (arrows).

On the day of admission to HV UFMG-VH, cervical and thoracic surgery was performed to correct the megaesophagus. During surgery, the presence of persistent right aortic arch with patent ductus arteriosus causing ventral compression of the esophagus, leading to esophageal dilation cranial to the base of the heart was confirmed. During surgery, the animal presented cyanotic mucous membranes. After surgery, due to moderate hypothermia, the animal remained on oxygen therapy and underwent gradual heating with warm packs. The next day, the animal suffered cardiac arrest. All attempts at recovery were unsuccessful, and finally, the animal died.

At necropsy, the animal exhibited very poor body condition with no subcutaneous adipose tissue, and the oral mucosa was moderately pale and cyanotic. Approximately $40 \mathrm{~mL}$ of translucent fluid (moderate hydrothorax) was observed in the thoracic cavity. The lungs were not completely collapsed and had a smooth, shiny surface and extensive dark-red color interspersed with whitish, multifocal areas, mainly located in the cranial ventral portions and affecting approximately $75 \%$ of the organ (Figure 2). After cutting the airways up to the bifurcation of the trachea, a significant amount of blood and whitish, frothy liquid was drained. A moderate quantity of a yellowish, viscous fluid flowed from the cut surface of the firm cranioventral areas of the lung.

Cytology imprints of the firm areas of the lung revealed an abundant number of macrophages containing a granular, refractive, and amorphous material in the cytoplasm (Figure 3). Histologically, the lung parenchyma exhibited abundant macrophages with cytoplasm filled by an amorphous refractive granular material distributed diffusely in the alveolar lumen, alveolar septa, and bronchiolar and bronchial lumen. A discrete amount of the same material was also observed free in the alveolar lumen (Figure 4). A multifocal discrete lymphocytic and neutrophilic alveolar infiltrate and moderate, diffuse congestion were also observed. When polarized light was applied to the areas with histiocytic infiltration, marked birefringence of the material located inside and outside histiocytes was observed (Figure 4b). 


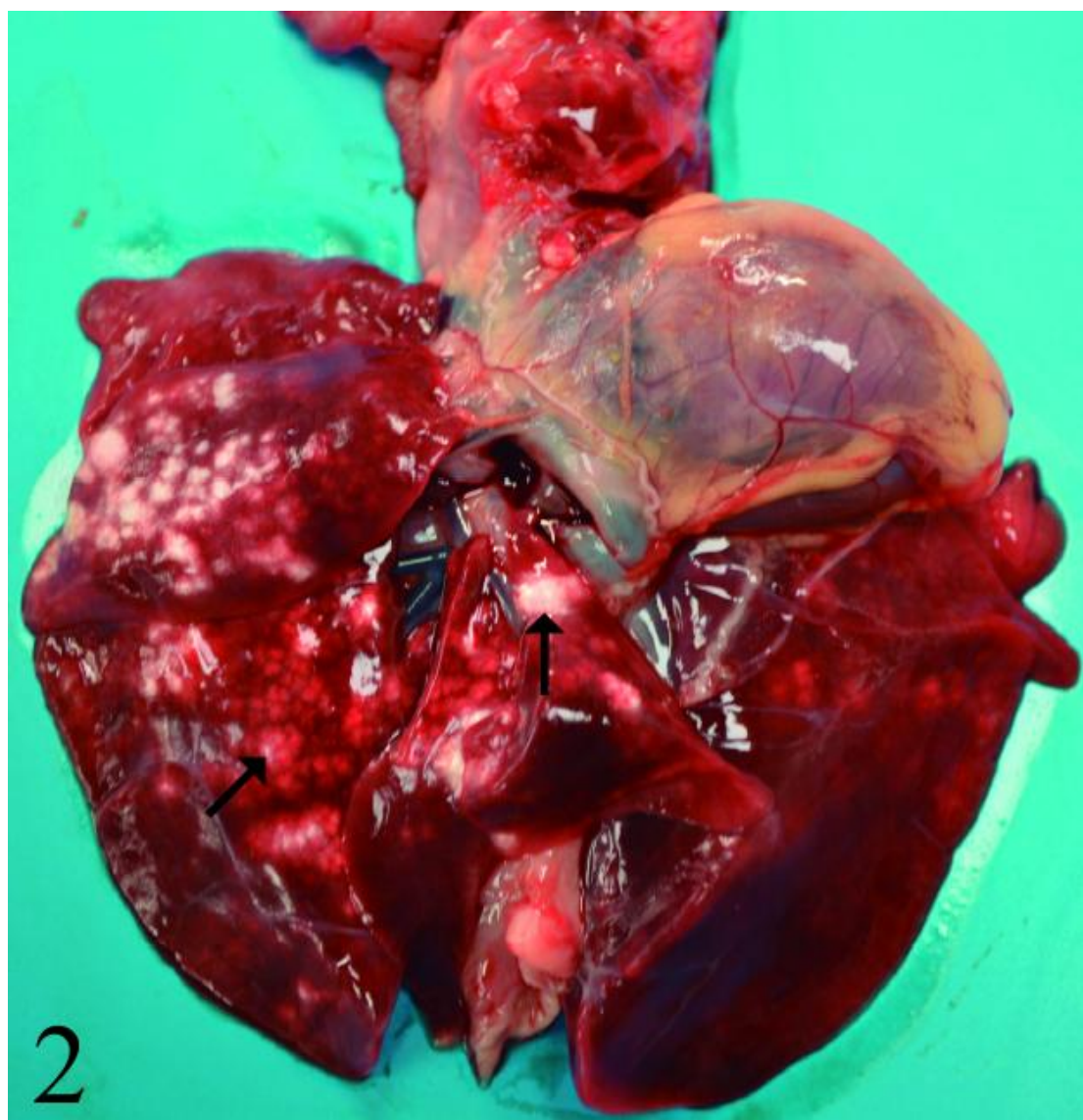

Figure 2. Lungs of a six-month-old female cat. Multifocal to coalescing whitish areas located in the cranial ventral portions of the lung (arrows).

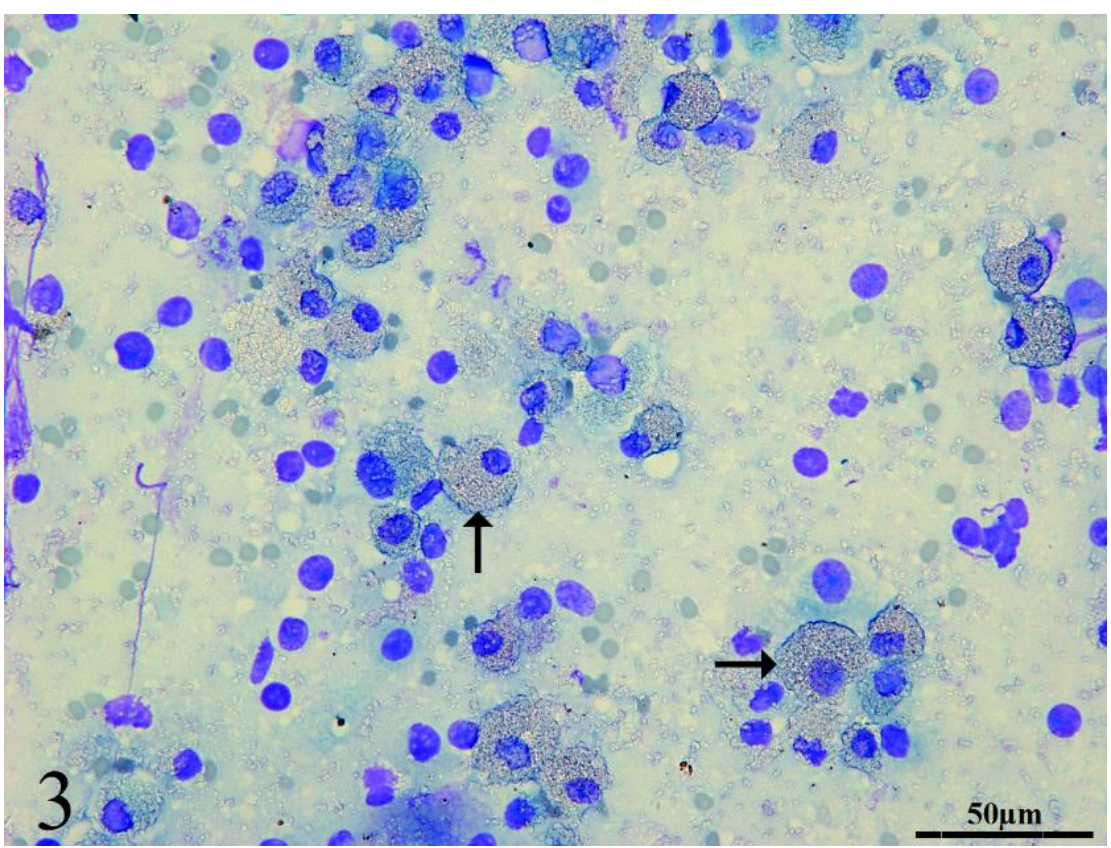

Figure 3. Cytology. Lung fluid of a six-month-old female cat. Macrophages containing granular

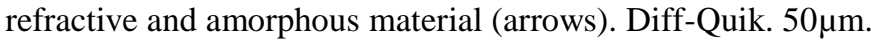




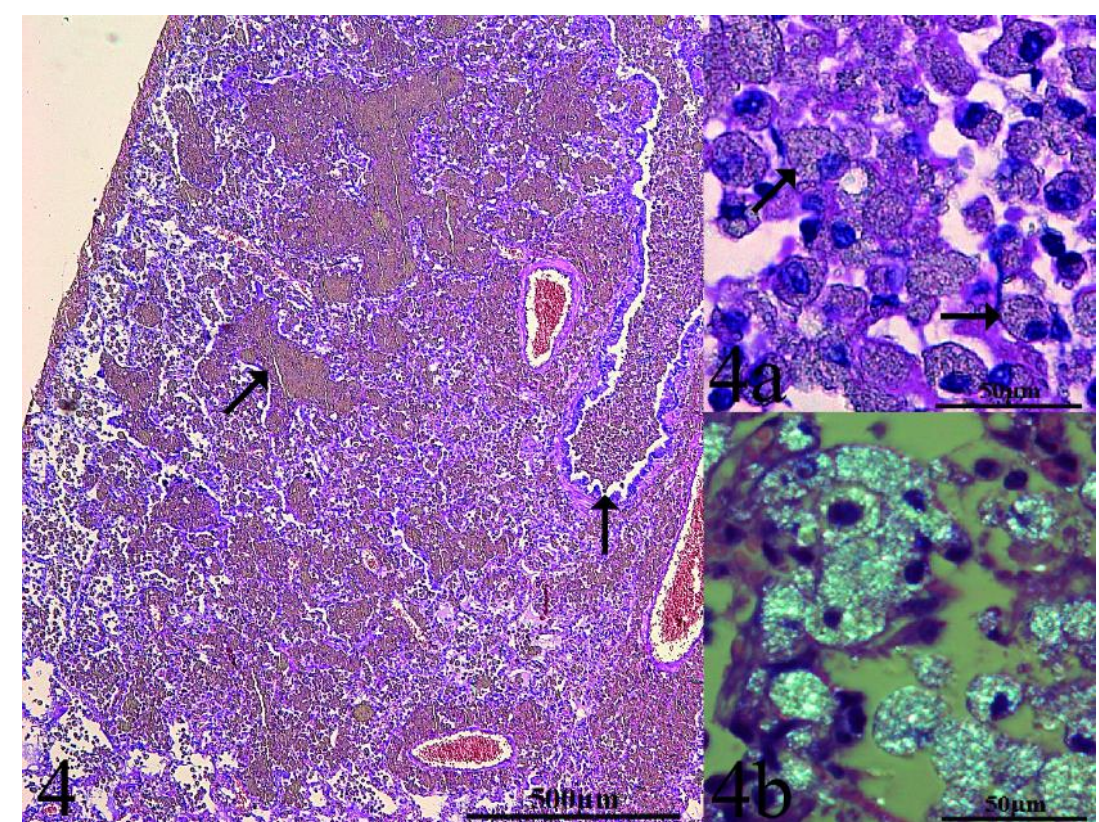

Figure 4. Lung, alveolar, bronchia, and bronchial lumen filled by macrophages with cytoplasms containing an amorphous refractive granular material (arrows). Hematoxylin and eosin stain. Bar, 500 $\mu \mathrm{m}$. Details: 4a) Macrophages containing barium sulfate in the cytoplasm (arrows). Hematoxylin and eosin

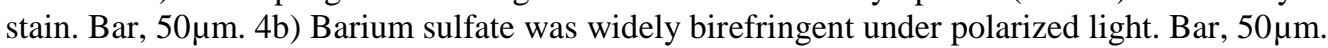

\section{DISCUSSION}

Based on the clinical history of the animal in the present report, along with the radiographic and necropsy findings, megaesophagus resulting from persistence of the right aortic arch was confirmed. This condition predisposes the animal to dysphagia, which led to aspiration of barium sulfate during the diagnostic procedure, as evidenced by the radiography findings. The material observed in macrophages in a cytology examination and in bronchi, bronchioles, and alveoli in a histological study using polarized light is compatible with barium sulfate.

It was not possible to determine the volume of barium sulfate used for the contrast radiography procedure, but we speculate that much more than the recommended dose for domestic animals was used, leading to the accumulation of this material in the bronchi, bronchioles, and alveoli and consequent severe respiratory distress, histiocytic pneumonia, and death.

Few reports have described megaesophagus secondary to dextroposition of the aortic arch in cats, and cases of pneumonia due to barium sulfate aspiration are even rarer in veterinary medicine (Wowk and Olson, 1980). To the best of our knowledge, this is the second case of barium sulfate aspiration pneumonia in cats (Forbes, 1989); however, this is the first report in veterinary medicine in which aspiration led to animal death.

\section{ACKNOWLEDGEMENTS}

The authors are thankful to Fapemig, CNPq and Capes for the finantial support. RMCG has a research fellowship from CNPq.

\section{REFERENCES}

FORBES, D.C.; Barium retention in the lungs of a cat. Can. Vet. J., v.30, p.509-510, 1989.

JACKSON M.; KAPUR, N.; GOYAL, V. et al. Barium aspiration in an infant: a case report and review of management. Front. Pediatr., v.2, p.14, 2014.

KATSANOULAS, C.; PASSAKIOTOU, M.; MOULOUDI, E. et al. Severe barium sulphate aspiration: a report of two cases and review of the literature. Signa Vitae, v.2, p.25-28, 2007.

KYLES, A.E. Esophagus. Surg. Small Anim. v.2, p.1461-1483, 2012. 
LEVINE, J.S.; POLLARD, R.E.; MARKS, S.L. Contrast Videofluoroscopy assessment of dysphagic cats. Vet. Radiol. Ultrasound, v.55, p.465-471, 2014.

MEOLA, S.; MAZZAFERRO, E.; WHEELER, J. et al. Medical and surgical management of severe barium aspiration in a dog. J. Vet. Emerg. Crit. Care, v.18, p.639-645, 2008.

SANTOS, F.C.; STEEN. B. Aspiration of barium contrast. Case Rep. Pulmonol., 2014, vailable in: <http://dx.doi.org/10.1155/2014/215832/>.

Accessed in: 1 Jun. 2016.
TREMOLADA, G.; LONGERI, M.; POLLI, M.; PARMA, P.; ACOCELLA, F. Persistent right aortic arch and associated axial skeletal malformations in cats. J. Feline Med. Surg., v.15, p.68-73, 2012.

WOWK, B.J.; OLSON, G.A. Megaesophagus produced by persistent right aortic arch in a cat. Vet. Med. Small Anim. Clin., v.75, p.77-83, 1980. 